\title{
Student Satisfaction Optimization Will Be The Quality of Learning Through The Exploration of Initial Decision Students Choose Private University in Bima City
}

\section{Aprianti Kartin ${ }^{1^{*}}$, Amirulmukminin ${ }^{2}$}

${ }^{12}$ Sekolah Tinggi Ilmu Ekonomi (STIE) Bima

\section{A R T I C L E I N F 0}

Article history:

Received 15 August 2019

Received in revised Form 29 September 2019

Accepted 18 October 2019

Available online 29

November 2019

\section{Keywords:}

Quality of Learning, Student Satisfaction, Decisions to Choose a College

\begin{abstract}
A B S T R A C T
This study aims to reveal the role of the initial decision of students choosing tertiary institutions through physical evidence, reference groups and self-motivation and their impact on student satisfaction with the quality of learning. Research methods conducted using the survey method. The sample in this study were active students at private universities in the city of Bima as many as 379 respondents using the Proportionate Stratified Random Sampling technique. Data analysis and hypothesis testing using regression analysis with the help of SPSS Version 20 for windows. The results showed that aspects of physical evidence, reference groups and self-motivation had a positive and significant role in the decision of students in choosing tertiary institutions. The impact of these student decisions also has a positive and significant effect on student satisfaction with the quality of learning of selected tertiary institutions. The implications of this study are directed to be able to maximize the dimensions that influence students' initial decisions in choosing tertiary institutions so as to optimize student satisfaction on the quality of learning starting from the input, process and output of learning-oriented to the aspects of services that are directly felt by students as recipients of educational services.
\end{abstract}




\section{Introduction}

Determination of which university to choose by prospective students is likened to a buyer who will buy an item or product. thus, universities can be analogous to institutions providing services to students. the tight competition in the "industry" of higher education in the city of bima is marked by the emergence of a variety of new tertiary institutions, this certainly influences the decision of prospective students to choose quality universities. based on the results of observations made by researchers, some students make spontaneous choices without good planning because they are tempted by promotions, services, building facilities, and others without doing a priority scale which is done first. there are some students who, when it has been running for two or three semesters, only realize that the decision taken is not as expected. this proves that determining the choice of lectures requires a rational process that is as objective as possible, because it will have long-term consequences and be associated with great sacrifice, starting from the preparation of time, funds and mental attitude of the student. a college must be able to know what is important for students, provide information to students that what they will provide is useful for students. in this study, several factors play a role for a prospective student before making his choice to one of the tertiary institutions of interest, including physical evidence, reference groups, and selfmotivation.

Sutartiah (2017) revealed that the physical evidence factor of tertiary institutions ranks first which influences students' decisions in choosing tertiary institutions. one strategy in increasing competitive advantage to attract public interest is by continuing to improve the quality of physical evidence. physical evidence is evidence that a college strives to provide quality learning processes. quality physical evidence will produce quality graduates as well. this will affect the reference group, one of which is alumni.

Alumni play an important role in influencing the decisions of prospective students in choosing tertiary institutions (widikusyanto and wibowo, 2015). through alumni, universities can convey messages, both the vision and mission of universities in real. alumni can also explain their impressions of being a student at a particular tertiary institution related to the physical form of the tertiary institution, the quality of learning and extracurricular activities. this is certainly very helpful for prospective students in determining their choices.

Fitria (2015) explains that in addition to external factors such as physical evidence and reference groups, internal factors also play a role for prospective students in determining tertiary institutions. one of the internal factors is self-motivation. before deciding to choose a college, prospective students usually already have achievement targets such as job opportunities, want to excel, or because of the wishes of parents. the target is a motivation for prospective students to make their choices.

After determining the choice of a tertiary institution, students begin to feel the products/services of the selected tertiary institution, one of which is through the quality of learning. student assessment of the quality of learning can be known through the level of student satisfaction. satisfaction in this study is interpreted as the level of students' feelings about the difference between what is expected and the situation given by higher education. students certainly expect selected universities to provide satisfying services to be able to develop their interests and talents.

Based on the results of research conducted by fitria (2015), the most dominant factor influencing a student's decision to choose a college is student self-motivation. whereas based on the results of research conducted by widikusyanto and wibowo (2015) the most dominant factor is the reference group in deciding which universities are of interest. results of research conducted by sutartiah (2017), the physical evidence factor of higher education ranks first which influences students' decisions in choosing tertiary institutions.

Septianna (2019) from the results of his research explained that the quality of service is one of physical evidence affecting student satisfaction. this is in line with the results of research conducted by prihatin (2019) that academic services consisting of physical facilities of tertiary institutions greatly affect the academic satisfaction of students. other research conducted by trisusanti and suryanti (2017) explains that the level of student satisfaction is strongly influenced by academic services including tertiary facilities as well as reference groups that recommend tertiary institutions. this shows that the decision of students when choosing tertiary institutions greatly influences the quality of services, especially facilities because it will have an impact on student satisfaction with the quality of learning.

In addition to external factors such as physical evidence and reference groups, internal factors also play a role for prospective students in determining tertiary institutions. one of the internal factors is selfmotivation. before deciding to choose a college, prospective students usually already have achievement targets such as job opportunities, want to excel, or because of the wishes of parents. the target is a motivation for prospective students to make their choices. 
The decision to choose a college has an impact on whether or not students will be satisfied with the Quality of learning provided by the chosen tertiary institution considering that the essence of the educational institution is the teaching and learning activities (learning process). quality as a "place to use" and emphasizes that the basic mission of the quality of an educational institution is "developing programs and services that meet the needs of users such as students and the community" (salis, 2012).

Quality learning boils down to the ability of educators in the learning process. it simply means the ability that must be possessed by educators to be able to plan learning, the learning process, and evaluation of learning (arifin and barnawi, 2012). students certainly expect selected universities to provide satisfying services to be able to develop their interests and talents. the satisfaction of the quality of learning intended in this study is the suitability of learning activities carried out by educators with the needs and expectations of students.

In contrast to previous studies which only investigated the influence of physical evidence, reference groups and motivations on university decision to choose and discuss them separately. this study reveals the role of students' initial decision to choose tertiary institutions through physical evidence, reference groups and self-motivation as well as analyzing the impact of these decisions on student satisfaction with the quality of learning. the final results of the research lead to an increase in student satisfaction with the quality of learning at selected tertiary institutions.

Based on the description above, so this study aims to "analyze the positive and significant role of physical evidence, reference groups, and self motivation partially and simultaneously on the initial decision of students choosing a private tertiary institution in the city of bima and analyzing the positive and significant impact of the decision on student satisfaction for the quality of higher education learning ".

Research on physical evidence, reference groups and self-motivation becomes important to be careful considering consumers (community/students) tend to pay attention to physical form before deciding on the choice of tertiary institution, which means paying attention to whether the tertiary institution is appropriate or not for the convenience and smoothness of the learning and teaching process . also, consumers must seek credible information through reference groups so that they can motivate themselves in strengthening their decisions to create trust in selected universities. this decision has an impact on whether or not consumers will be of the quality of learning provided by selected tertiary institutions, remembering that the essence of educational institutions is teaching and learning activities (learning process).

\section{Methods}

This research uses a quantitative approach with the method used is a survey research method. The research will be conducted at Universities in Bima city. The population in this study were active students in the 2017/2018 school year at STIE Bima, STIH Muhammadiyah Bima, STKIP Bima and STISIP Bima totaling 7,200 students.

The sampling technique used is probability sampling, that is the Proportionate Stratified Random Sampling technique. To determine the sample size in this study using the slovind formula with a significance level of $5 \%$ so that the sample in this study was 379 students.

The data collection method uses direct techniques in the form of a questionnaire that the respondents fill in themselves by 40 statement items. The statements submitted in the questionnaire relate to the variables in this study, namely physical evidence (X1), reference groups (X2), self-motivation (X3), the initial decision of students choosing college (Z) and student satisfaction with the quality of learning $(\mathrm{Y})$.

The validity test in this study used the item discrimination test, namely the Pearson productmoment correlation (PPM). The measurement criteria are $r_{\text {count }}>r_{\text {table }}$ then the question item is declared valid (sugiyono, 2010). Based on the results of the analysis showed that of the 40 items submitted statements were all declared valid.

Furthermore, the reliability test of this research instrument uses cronbach's alpha analysis, considered reliable if $a>0,60$ (Suharsimi, 2010). Based on the results of the analysis of the reliability of instruments obtained by higher education physical evidence instruments have an alpha coefficient of 0.865 , and self-motivation has an alpha coefficient of 0.813 , while the initial decision of students choosing a college has an alpha coefficient of 0.828 and student satisfaction with the quality of learning has an alpha coefficient of 0.883 . So it is stated that the instruments used in this study have a high level of reliability (reliable). 
After testing the validity and reliability of the instrument, the next step is to conduct a prerequisite test for data analysis (classical assumptions) consisting of a normality test, a multicollinearity test, and a heteroscedasticity test.

The normality test in this study was carried out with the Kolmogorov-Smirnov Test where the results of the analysis showed the significance value of the variables $\mathrm{X} 1, \mathrm{X} 2$, $\mathrm{X} 3$ to $\mathrm{Y}$ was $\alpha=0,173>0,05$ and the significance value of the variable $\mathrm{Z}$ against $\mathrm{Y}$ was $\alpha=0,056>0,05$ so meet the normality requirements .

In the multicollinearity test obtained tolerance value $\leq 0.10$ and VIF value $\leq 10$ so that all instruments of this research variable did not occur multicollinearity. Furthermore, the heteroscedasticity test obtained the results of the analysis on the Scatterplot which showed that there were no specific patterns and the data spread above and below the number 0 on the Y-axis so that there were no symptoms of heteroscedasticity. Data analysis and hypothesis testing using regression analysis with the help of SPSS Version 20 for windows.

\section{Result And Discussion}

A good regression equation model is one that has met the classical assumption test that is all data are normally distributed, the model is free from the symptoms of multicollinearity and heteroscedasticity. Based on the results of the classical assumption test analysis it has been proven that the research model meets the classical assumption requirements so that it is considered good (Suharsimi, 2010).

In testing hypotheses, researchers used multiple linear regression analysis to determine the positive and significant influence of physical evidence (X1), reference groups (X2), self motivation (X3) on the initial decision of college students $(Z)$ and use simple regression analysis to determine the impact of the initial decision of students choosing a college $(Z)$ on student satisfaction with the quality of learning (Y).

Table 1. Results of Multiple Linear Regression Tests

\begin{tabular}{|c|c|c|c|c|c|c|}
\hline & \multicolumn{6}{|c|}{ Coefficients $^{\mathbf{a}}$} \\
\hline \multirow{6}{*}{1} & \multirow{2}{*}{ Model } & $\begin{array}{c}\text { Unstandardized } \\
\text { Coefficients }\end{array}$ & & $\begin{array}{c}\text { Standardized } \\
\text { Coefficients }\end{array}$ & \multirow{2}{*}{$\mathbf{t}$} & \multirow{2}{*}{ Sig. } \\
\hline & & B & $\begin{array}{l}\text { Std. } \\
\text { Error }\end{array}$ & Beta & & \\
\hline & (Constant) & 8,339 & 1,302 & & 6,404 & 000 \\
\hline & PHISICAL_EVIDENCE_X1 &, 044 &, 042 & 049 & 1,049 & 000 \\
\hline & GROUP_REFERENSI_X̄2 & 237 & ,044 & 261 & 5,423 & 000 \\
\hline & SELF_MOTIVATION_X3 & , 476 &, 050 &, 472 & 9,538 &, 000 \\
\hline
\end{tabular}

Based on table 1. The regression equation obtained is $\mathrm{Y}=8.333+0.044 \mathrm{X} \_1+0.237 \mathrm{X} \_2+0.476 \mathrm{X} \_3$, where the regression efficiency is positive.

For hypothesis 1 (H1), physical evidence has a positive and significant influence on the initial decision to choose a private tertiary institution in Kota Bima, where $t_{\text {count }}=1.049$ and a significance of $0.000<0.05$ so that the hypothesis is accepted. These results support the results of Rakhman's study (2018) which states that physical evidence has a positive and significant effect on the initial decision to choose a tertiary institution.

For hypothesis $2(\mathrm{H} 2)$, the reference group has a positive and significant influence on the initial decision to choose a private tertiary institution in Kota Bima, where $t_{\text {count }}=5.423$ and a significance of $0.000<0.05$, so hypothesis 2 (H2) is accepted. These results support the research results of Puspitasari and Patrikha (2018) which states that the reference group has a positive and significant effect on the initial decision to choose tertiary institutions. The research also explained that the reference group is the first aspect that has the most dominant influence on the initial decision of students choosing universities.

For hypothesis 3 (H3), the self-motivation variable has a positive and significant influence on the initial decision to choose a private tertiary institution in Kota Bima, where $t_{\text {count }}=9.538$ and the significance of $0.000<0.05$, so hypothesis 3 (H3) is accepted. These results support the results of research by Puspitasari and Patrikha (2018) which states that self-motivation has a positive and significant effect on the initial decision to choose a tertiary institution, and it is also explained that self-motivation is the third dominant aspect that has a dominant influence on the initial decision of a student to select a tertiary institution. 
Table. 2. Simultaneous F Test

\begin{tabular}{|c|c|c|c|c|c|c|}
\hline \multicolumn{7}{|c|}{ ANOVA $^{a}$} \\
\hline No & Model & Sum of Squares & $\mathrm{df}$ & Mean Square & $\mathrm{F}$ & Sig \\
\hline \multirow[t]{3}{*}{1} & Regression & 4519,071 & 3 & 1506,357 & 113,490 & ,000 \\
\hline & Residual & 4977,410 & 375 & 13,273 & & \\
\hline & Total & 9496,480 & 378 & & & \\
\hline
\end{tabular}

a. Dependent Variable: KEPUTUSAN_MEMILIH_PERGURUAN_TINGGI_Z

b. Predictors (Constant). MOTIVASI_DIRI_X3. PHISICAL_EVIDENCE_X1.KELOMPOK_REFERENSI_X2

Based on table 2. For hypothesis 4 (H4) it can be seen that physical evidence, reference groups, and self-motivation simultaneously have a positive and significant role in the initial decision to choose a private tertiary institution in the City of Bima, where $F=5.423$ and significance $0.000<0.05$, so that hypothesis 4 (H4) is accepted. These results support the results of Ruhiyat's (2010) study which states that physical evidence, reference groups, and self-motivation simultaneously have a positive and significant effect on the initial decision to choose a tertiary institution.

Ruhiyat (2010) explains that aspects of physical evidence, reference groups and self-motivation are the best combinations as the most dominant aspect in influencing students' initial decisions in choosing tertiary institutions.

Table 3. Simple Regression

\begin{tabular}{|c|c|c|c|c|c|c|c|c|c|}
\hline \multicolumn{10}{|c|}{ Coefficients $^{a}$} \\
\hline \multirow[t]{2}{*}{$\begin{array}{l}\mathrm{N} \\
\mathrm{O}\end{array}$} & Model & $\begin{array}{l}\text { Unstanc } \\
\text { Coeffici }\end{array}$ & $\begin{array}{l}\text { dized } \\
\text { s }\end{array}$ & $\begin{array}{l}\text { Standar } \\
\text { dized }\end{array}$ & & & & & \\
\hline & & B & $\begin{array}{l}\text { Std. } \\
\text { Error }\end{array}$ & Beta & $\mathrm{t}$ & Sig & $\begin{array}{l}\text { Fractio } \\
\mathrm{n} \\
\text { Missin } \\
\text { g Info }\end{array}$ & $\begin{array}{l}\text { Relative } \\
\text { Increase } \\
\text { Variance }\end{array}$ & $\begin{array}{l}\text { Relativ } \\
\text { e } \\
\text { Efficie } \\
\text { ncy }\end{array}$ \\
\hline 1 & $\begin{array}{l}\text { (Constant) } \\
\text { KEPUTUSAN_- } \\
\text { MEMILIH_PERGU } \\
\text { RUAN-TINGGI_Z }\end{array}$ & $\begin{array}{l}11,670 \\
, 623\end{array}$ & $\begin{array}{l}1,357 \\
, 043\end{array}$ & ,597 & $\begin{array}{l}8,598 \\
14,447\end{array}$ & $\begin{array}{l}\text {,000 } \\
, 000\end{array}$ & & & \\
\hline
\end{tabular}

a. Dependent Variable: KEPUASAN_MUTU_PEMBELAJARAN_Y

In the hypothesis (H5) based on table 3 , it can be seen that the initial decision of students choosing tertiary institutions has a positive and significant impact on student satisfaction with the quality

of learning. where $t_{\text {count }}=14.474$ and significance $0.000<0.05$, therefore, hypothesis 5 (H5) is accepted. These results support the research of Ruhiyat (2010) which states that the initial decision to choose a university will lead to the satisfaction of students as recipients of educational services.

Table 4. Coefficient of Determination

\begin{tabular}{|c|c|c|c|c|c|c|}
\hline \multicolumn{7}{|c|}{ Model Summary } \\
\hline No & Model & $\mathrm{R}$ & R Square & $\begin{array}{l}\text { Adjusted } \\
\text { Square }\end{array}$ & $\mathrm{R}$ & $\begin{array}{l}\text { Std. Error of } \\
\text { the Estimate }\end{array}$ \\
\hline 1 & & 690 & ,476 &, 472 & & 3,643 \\
\hline
\end{tabular}

a. Predictors (Constant). MOTIVASI_DIRI_X3. PHISICAL_EVIDENCE_X1.KELOMPOK_REFERENSI_X2

Based on table 4. Above can be seen that the results of the coefficient of determination amounted to 0.476 . This can explain that the magnitude of the role of physical evidence, reference groups and selfmotivation towards the initial decision of college students to choose is $47.6 \%$ while the remaining $52.4 \%$ is influenced by other factors not examined in this study.

The results of this study also prove that physical evidence, reference groups, and self-motivation in this study had a high contribution (0.690) to the initial decision of students choosing universities. 
Table 5. Coefficient of Determination

\begin{tabular}{|c|c|c|c|c|c|c|}
\hline \multicolumn{7}{|c|}{ Model Summary } \\
\hline No & Model & $\mathrm{R}$ & R Square & $\begin{array}{l}\text { Adjusted } \\
\text { Square }\end{array}$ & $\mathrm{R}$ & $\begin{array}{l}\text { Std. Error of } \\
\text { the Estimate }\end{array}$ \\
\hline 1 & &, 597 & ,356 & ,355 & & 4,204 \\
\hline
\end{tabular}

a. Predictors: (Constant. KEPUTUSAN_MEMILIH_PERGURUAN TINGGI_Z

b. Dependent Variable: KEPUASAN_AKAN_MUTU_PEMBELAJARAN_Y

Based on table 5. Above can be seen that the results of the coefficient of determination amounted to 0.356. This can explain that the magnitude of the impact of the initial decision of students choosing a college on student satisfaction with the quality of learning is $35.6 \%$ while the remaining $64.4 \%$ is influenced by other factors not examined in this study. This also proves that the impact of the initial decision of students choosing tertiary institutions in this study had a high contribution (0.579) on student satisfaction with the quality of learning.

Based on the results of hypothesis testing starting from hypothesis 1 (H1), hypothesis 2 (H2), hypothesis 3 (H3), hypothesis 4 (H4) and hypothesis 5 (H5) it is clear that all variables in this study have positive and significant influence, which means aspects physical evidence, reference groups, and selfmotivation have a positive and significant role partially and simultaneously on the initial decision of students choosing a private university in the City of Bima and the impact of the decision also has a positive and significant effect on student satisfaction with the quality of learning.

\section{Conclussion}

Based on the results of data analysis and hypothesis testing that has been done it can be concluded that physical evidence, reference groups, and self-motivation play a positive and significant role in the initial decision of students choosing universities by $47.6 \%$. as well as the impact of the decision has a positive and significant effect on student satisfaction with the quality of learning by $35.6 \%$.

The results of this study indicate that to optimize student satisfaction with the quality of learning, it is necessary to improve and increase aspects of physical evidence and reference groups as external factors. This can strengthen internal factors in the form of self-motivation so that it can positively influence the initial decision in choosing a tertiary institution.

The results of this study also show that aspects of physical evidence, reference groups and selfmotivation are not stand-alone aspects, but rather are integrated and affect the initial decision of students in choosing a private university in the City of Bima. the student's decision will affect student satisfaction on the quality of learning comprehensively. In other words, these aspects will not work alone in a learning environment must work together to create a learning experience that can increase student satisfaction.

Optimizing student satisfaction with the quality of learning by knowing the dimensions that influence students' initial decisions in choosing a private tertiary institution in Kota Bima proves that students in determining the chosen tertiary institution have many factors that influence it, therefore private tertiary institutions in the City must always improve the quality of the tertiary institution high in order to increase student satisfaction.

The implication of this research is directed so that private universities in the City of Bima can maximize the quality of physical facilities and learning process devices. through this research it is also expected to be an evaluation and consideration for management, especially the quality of tertiary institutions in the formulation of policies, the determination of promotion programs, the determination of the provision of learning facilities and other supporting facilities and infrastructure in order to increase student satisfaction with the quality of tertiary institutions in the City of Bima.

\section{Reference}

Arifin dan Barnawi . 2012. Kinerja Guru Profesional. Yogyakarta: Aruzz Media

Edward, Salis. 2012. Total Quality Manajement in Education. Manajemen Mutu Pendidikan. Yogyakarta: IRCiSod

Fitria, Hadiyati. 2015. Faktor-Faktor yang Mempengaruhi Minat Mahasiswa memilih Perguruan Tinggi Ekonomi Islam (Studi Kasus: STEI SEBI). STIE SEBI. Jurnal Ekonomi dan Perbankan Syariah. 
Puspitasari, Anggriani dan Patrikha, Finisica.D. (2018). Analisis Faktor-Faktor yang Mempengaruhi Keputusan Pemilihan Universitas Pada Siswa Kelas XII SMA Negeri 22 Surabaya. Jurnal Pendidikan Ekonomi, Manajemen dan Keuangan. Vol 2 No. 1 Mei 2018 (1-10).

Prihatin, Khristina Sri dan Dewi Yohanna Selvia. 2019. Pengaruh Pelayanan Akademik Terhadap Tingkat Kepuasan Mahasiswa Universitas Banten Jaya (UNBAJA). Jurnal Pendidikan, Akuntansi dan Keuangan UNBAJA. : Volume 2, Nomor 1. ISSN: 2662-7037.

Rakhman, faisal. (2018). Pengaruh people, proses dan physical Evidence terhadap Keputusan Mahasiswa Memilih STIBANKS Al Ma'Soem (Tahun Akademik 2017/2018). Jurnal Riset Bisnis dan Investasi. Vol 4, No 3, Desember 2018. ISSN 2460-8211.

Ruhiyat, Endang (2010). Analisis Faktor yang menjadi Penentu Mahasiswa dalam Memilih Perguruan Tinggi. Jurnal Ilmiah dan Ilmu Manajemen: Univeristas Pamulang.

Septiana, Agatha dkk. 2019. Analisis Pengaruh Kualitas Jasa Pelayanan Terhadap Kepuasan Mahasiswa. Jurnal Keuangan dan Bisnis. DOI: 10.32524/jkb.v17l.432

Suharsimi,Arikunto (2010). Prosedur Penelitian Suatu Pendekatan dan Praktik. Jakarta: Rineka Cipta.

Sugiyono, P. D. (2011). Metode Penelitian Kuantitatif dan Kualitatif dan R\&D. Bandung: Alfabeta.

Sutartiah, Farliana. 2017. Evaluasi Kepuasan Mahasiswa Terhadap Kualitas Pelayanan Pendidikan Lembaga pendidikan Tinggi ABC di Cikarang. Jurnal Formatif: Volume 7, Nomor 1. ISSN: 2088-351x.

Trisusanti, Denok dan Suryanti, Nunuk. (2017). Pengukuran Tingkat Kepuasan Mahasiswa Terhadap Pelayanan Pendidikan Di Fakultas Keguruan Dan Ilmu Pendidikan. Perspektif Pendidikan Dan Keguruan. Volume VIII, nomor 2. ISSN: 2579-9525

Widikusyanto, M.Johan dan Wibowo, A. Hermansyah. 2015. Keputusan memilih Unsera untuk melanjutkan Studi Faktor-Faktor yang Mempengaruhinya. Jurnal Sains Manajemen: Volume 1, Nomor 2, hal 21-35. ISSN: 2443-0064 